UDC 821.512.162

DOI https://doi.org/10.24919/2308-4863/39-1-12

\author{
Nuray BEKTASHI, \\ orcid.org/0000-0002-1709-7609 \\ Postgraduate Student, \\ Researcher at the Department of Music and Theater \\ Institute of Art, Language and Literature \\ of the Nakhichivan Branch of the National Academy of Sciences of Azerbaijan \\ (Nakhichevan,Azerbaijan)bektasinuray@gmail.com
}

\title{
A LOOK AT THE DEVELOPMENT OF MUSIC IN NAKHCHIVAN
}

The article traces the formation of musical art in Nakhchivan, the historical development of this art, folk games and performances, music-performance-dance harmony in everyday ceremonies, which are important stages in the formation of musical culture in this ancient land. They also spoke about the development of music in Nakhchivan in the Middle Ages, the environment that caused it, the activities of prominent musicians known for their Nakhchivan people, promoting our national music and Nakhchivan. At the beginning of the XIX-XX centuries in Nakhchivan, the contribution of Eastern trios, ashug music, mugam singing to the development of music in Nakhchivan was studied in detail, with reference to scientific sources, and involved in research. It was noted that the fact that Nakhchivan is one of the oldest cultural centers in Azerbaijan and the Middle East gives grounds to say that along with other areas of culture, the art of music has its own way of development. In general, when talking about the development of music in Nakhchivan in the Middle Ages, several directions can be identified. It should be noted that the art of dance, which has ancient historical roots, along with music, has developed in Nakhchivan, improved with the specific features of this region and played a role in the formation and enrichment of 'Yalli', which is invaluable in the cultural treasury of Nakhchivan. One of the important directions in the development of our national music is the performing art formed in the form of oriental trio, mugam trio. It should be noted that our music culture, formed in folk games and ceremonies, formed in the synthesis of music-dance-performance, has matured over time and specialized in the form of trio. It should be noted that the art of dance, which has ancient historical roots, along with the formation of music, has a unique way of development in Nakhchivan, improving its specific features and played a role in the formation and enrichment of 'Yalli', which is invaluable in the cultural treasury of Nakhchivan. Among the singers working in Nakhchivan in the late 19th and early 20th centuries, we can name Mashadi Hasan, Mashadi Asad, Mashadi Abil, Mashadi Ismayil, Hasangulu, Idris Nagiyev among the artists who have their own voice and style of performance. Idris Nagiyev's 'Shur' classification, Hasangulu's 'Heyrati', Mashadi Ismayil's 'Shahnaz' performance, which are still in the language of music lovers, show their mastery in the art of singing.

Key words: Nakhchivan, music culture, performance, Azanchi Bakhshali, ashug art, Eastern trio.

\section{Нурай БЕКТАШІ, orcid.org/0000-0002-1709-7609} аспірант,

науковий співробітник відділу музики і театру Інституту мистецтва, мови та літератури Нахічеванського відділення Національної академї наук Азербайджану (Нахічевань, Азербайджан) bektasinuray@gmail.com

\section{ПОГЛЯД НА РОЗВИТОК МУЗИКИ В НАХЧІВАНІ}

У статті простежується становлення музичного мистецтва в Нахчивані, історичний розвиток изього мистецттва, народні ігри та вистави, музично-виставно-танцюювальна гармонія в повсякденних обрядах, які є важливими етапами формування музичної культури на цій давній землі. Вони також розповіли про розвиток музики в Нахчивані в середні віки, про середовище, яке його спричинило, про діяльність видатних музикантів, відомих своїм нахчиванським народом, пропаганду нашої національної музики та про Нахчиван. На початку XIX-XX століть у Нахчивані внесок східних тріо, музики ашугів, співів мугам у розвиток музики в Нахчивані детально вивчався із посиланням на наукові джерела та залучався до досліджень. Було відзначено, щуо той факт, що Нахчиван $\epsilon$ одним із найстаріших культурних цеентрів в Азербайджані та на Близькому Сході, дає підстави стверджувати, щчо поряд з іншими сферами культури музичне мистецтво має свій шлях розвитку. Загалом, говорячи про розвиток музики в Нахчивані в середні віки, можна виділити кілька напрямків. Слід зазначити, щчо танцюювальне мистецтво, яке має давнє історичне коріння, поряд з музикою, розвивалося в Нахчивані, вдосконалювалося $з$ урахуванням специфічних особливостей изього регіону і відігравало роль у формуванні та збагаченні 'Яллі', щзо $\epsilon$ безцінним в культурній скарбниці Нахчивана. Одним із важливих напрямків розвитку нашої національної музики є виконавське мистецтво, сформоване у формі східного тріо, тріо тияат. Слід зазначити, щуо наша музична 
культура, сформована в народних іграх та обрядах, сформована в синтезі музично-таниювального виконавства, з часом визріла і спеціалізується на формі тріо. Слід зазначити, щзо танцювальне мистецтво, яке має давнє історичне коріння, поряд із формуванням музики, має унікальний шлях розвитку в Нахчивані, покрашуючи його специфічні риси і відіграло роль у формуванні та збагаченні 'Яллі', щчо є неоціненним у культурній скарбниці Нахчивана. Серед співаків, які працювали в Нахчівані наприкінці 19 - початку 20 століття, можна назвати Машаді Хасан, Машаді Асад, Машаді Абіль, Машаді Ісмаїл, Хасангулу, Ідріс Нагієв серед артистів, які мають власний голос та стиль виконання. Класифікація «Шур» Ідріса Нагієва, «Хейраті» Хасангулу, виступ «Шахназ» Масхаді Ісмаїла, які досі звучать мовою меломанів, демонструють своє майстерність у співочому мистецтві.

Ключові слова: Нахчиван, музична культура, перформанс, Азанчі Бахшалі, мистецтво ашугів, східне тріо.

Introduction. The fact that Nakhchivan is one of the oldest cultural centers in Azerbaijan and the Middle East gives grounds to say that along with other areas of culture, there is a unique way of development of music. In general, when talking about the development of music in Nakhchivan in the Middle Ages, several directions can be identified. In addition to discussing the origin and development of the art of music in musicology, certain classifications have been made. One of these stylistic ideas says: '... Ashug music and mugam art form the basis of Azerbaijan's classical music' (Karimov, 2006: 17). As noted, these two directions will be leading when we talk about the development of music culture in Azerbaijan, as well as in Nakhchivan in the Middle Ages.

Thus, the harmony of music and dance in folk games and ceremonies, this field has played a special role in the formation of national dance and music culture. In his research, he spoke about Azerbaijani folk dances and the harmony of music and dance in these dances, drawing attention to the role of music in national dances in Nakhchivan: "The nature of music sometimes changes depending on where it is performed. For example, in Nakhchivan, 'Tarakeme' is played a little faster, faster, even naughty. In Baku or Karabakh, the dance is calm, melancholy. The dancer who plays it is like a swimmer.

Discussion. Ancient dance tunes and dance forms have undergone a number of changes over time. During this transition period, they change depending on the imagination of the performers, the conditions of development, the character of the people, its traditions, acquire new characteristics ' (Hasanov, 1983a: 21). As can be seen, when talking about Azerbaijani folk dances, the peculiarities of these dance and musical elements in Nakhchivan were emphasized. As a result of the research, it is emphasized that the example of Nakhchivan in the art of national music and dance has often been distinguished. Thus, speaking about the dance 'Towel', the researcher emphasizes that this dance was created in 1932 by tar player Nasir Nasirov. 'Most of the dances are performed by girls. In Nakhchivan it is sometimes played by boys "(Hasanov, 1983b: 35). This idea in itself reveals the fact that national dances are widespread in Nakhchivan.
It is interesting that the performance of our ancient national dances by boys and girls in Nakhchivan gives grounds to say that the interest in art and music in Nakhchivan has historical roots.

It should be noted that the art of dance, which has ancient historical roots, along with music, has developed in Nakhchivan, improved with the specific features of this region and played a role in the formation and enrichment of 'Yalli', which is invaluable in the cultural treasury of Nakhchivan. One of the unique folk games performed at such folk ceremonies, the game 'chinginchingi' was chosen because it is specific to the land of Nakhchivan, and it has been mentioned in scientific sources. 'Chingizchingi - one of the yalli-like games demonstrated at mass festivities in Nakhchivan and Mugan' (El-oba game folk performance,1984: 244), the unity of music and dance is also reflected in the game.

It should be noted that the role of music and dance in folk games and ceremonies is reflected in research, and it is clear that games are an integral part of our national culture as a unifying point of folklore and art. Along with games where music, words and dance are performed together, folk songs are also an important part of our national culture. Uzeyir Hajibeyli, a prominent composer and genius, clarified this point: both are of great ethnographic importance" (Hacibeyli, 2005: 412). It is clear from this that the genius composer also generalizes his ideas by grouping music performances individually and collectively. Based on the approach to these criteria, "oral music samples" (Oral traditional Azerbaijani music, 2016) are of interest in the work on collection, recording and systematization of music samples formed both in the context of dance-music-performance and on the basis of individual performance.

Numerous information on the development of the art of music in Azerbaijan in the Middle Ages, the main directions and prominent figures of this period is reflected in the research. Thus, Safiaddin Urmavi (1201-1294), known as the great philosopher and musicologist of the East, spoke about the high development of music in the works of Abdulgadir Maragai and Yusif Shah brothers and others, as well as in the works of medieval poets. 
One of the important directions in the development of our national music is the performing art formed in the form of oriental trio, mugam trio. It should be noted that our musical culture, formed in folk games and ceremonies, formed in the synthesis of music-dance-performance, has matured over time and specialized in the form of trio. It should be noted that the art of dance, which has ancient historical roots, along with music, has developed in Nakhchivan, improved with the specific features of this region and played a role in the formation and enrichment of 'Yalli', which is invaluable in the cultural treasury of Nakhchivan. 'Sources confirm that the famous musicians who were the pupils of this land took part in musical gatherings in the palaces of the Safavid, Ottoman and other Eastern rulers. For example, the most famous charlatan in the palace of the Ottoman ruler Murad IV was Murad agha from Nakhchivan. A monument with a saz image was also recorded in Kechili village of Shahbuz region. There, on a tombstone in the shape of a large box, belonging to the pre-monumental period in Duylun and Julfa, the image of a reed and a sword is engraved" (Modern problems of socio-economic and cultural development of the Nakhchivan Autonomous Republic, 1998: 53). It should be noted that the art of dance, which has ancient historical roots, along with the formation of music, has a unique way of development in Nakhchivan, improving its specific features and played a role in the formation and enrichment of 'Yalli', which is invaluable in the cultural treasury of Nakhchivan. In this sense, the pedagogue R. Huseynzadeh, who studies the history of pedagogical thought in Azerbaijan, notes that 'in the Middle Ages, especially in the XI-XII centuries, Nakhchivan was the capital of the Atabeylar state, where secular madrasas functioned' (Huseymzade, 2007: 136). Undoubtedly, the existence of madrasah-type educational institutions in Nakhchivan from that time, the modern type of education and the influence of such realities created the basis for the development of musicians among a number of prominent personalities who grew up during this period. This performing art, which was formed in the late 19th century, has expanded since the beginning of the last century. Thus, 'there are not many artists in our history of folk music who have such skills: Haji Husu, Sadig Asad oglu, Jabbar Qaryagdi oglu, Mirza Mahammad Hasan, Gurban Pirimov, Seyid Shushinsky, Khan Shushinsky and others' (Mammadov, 1981: 22 ). In the ancient land of Nakhchivan, which is an integral part of Azerbaijan, there was a unique way of this art, prominent figures. "Singing was mainly spread in Ordubad and Nakhchivan. The famous musician Murad agha acted as a court musician of the Ottoman sultan Murad IV of Nakhchivan. Artists such as Jabbar Qaryagdioglu and Bulbul had an exceptional contribution to the preservation of this art. "(Khahramanov, 2017: 121-125). This gives us reason to say that the art of music in Nakhchivan, especially singing, has developed since the Middle Ages, and has a place in our cultural history with its unique performers. In the next stage, the singer Sattar, who was famous for his unique style of performance in the 18th century, moved to Nakhchivan in 1844 and lived and worked there for two years. if it was important, on the other hand, it laid the groundwork for the growth of their successors. It was the result of the interest in the art of music and singing that a new generation of singers grew up in Nakhchivan in the late 19th and early 20th centuries.

Among the singers working in Nakhchivan in the late 19th and early 20th centuries, we can name Mashadi Hasan, Mashadi Asad, Mashadi Abil, Mashadi Ismayil, Hasangulu, Idris Nagiyev among the artists who have their own voice and style of performance. Idris Nagiyev's 'Shur' classification, Hasangulu's 'Heyrati', Mashadi Ismayil's 'Shahnaz' and others are still in the language of music lovers. their performance shows their mastery in the art of singing.

Let us clarify one point in particular that we can classify two groups in the performing arts during this period. Among them were performers who took part in religious ceremonies and lamentations, and some of them sometimes sang, that is, they served to revive our national music. In the other group, we can mention the artists who are professionally engaged in singing. Thus, such personalities as Molla Abdulla, Azanchi Bakhshali, the father of Huseyn Javid, a prominent representative of Azerbaijani romantic literature, were mainly engaged in singing in religious ceremonies, but also in singing. 'Shur' and 'Segah' mugams performed by Karbalai Bakhshali were filmed in 1905 in Tbilissi (Tbilisi). His charming voice and high appreciation of his voice are also reflected in the sources of the period. Thus, Azanchi Bakhshali, whose voice was damaged by an accident, then engaged in reciting the call to prayer in mosques. We read in the memoirs of Ali Sabri Gasimov, who has a special place in the history of twentieth-century Nakhchivan literary and public opinion, about his charming voice, performance and recitation of the call to prayer: "I remember: There was a Karbala Bakhshali. He used to call to prayer well. Especially close to the morning. I didn't really understand what he was saying, but because his voice was so beautiful and pleasant, I would go up to the roof every morning and wait for him to pray. 
Bakhshali of Karbala used to sing at weddings and folk festivals ... I witnessed how he sang 'Segah-zabul' and later, when I lost my mind, I regretted that Haji Bakhshali sings minajat and mugham? " (Kasumov,1983: 127-128).

Conclusions. The path of Nakhchivan musical culture, formed on the basis of deep-rooted traditions, gives grounds to say that the art of music has developed at a high level in this ancient land since the Middle Ages. The emergence and formation of musical culture in Nakhchivan has long historical roots. The presence of dance scenes in Gamigaya paintings in Nakhchivan gives grounds to say that culture in this land has been formed since prehistoric times. The fact that Nakhchivan was the capital of the Atabeylar state in the Middle Ages laid the foundation for cultural progress here, and Nakhchivan musicians gained great prestige in the Ottoman palace. The development of Eastern trios and ashug music in the 19th century laid the foundation for a new stage in the development of music culture. From the beginning of the last century, the art of music was professionally formed in Nakhchivan, the formation of music groups, the establishment of music schools influenced the rapid development of Nakhchivan music.

1. El-oba oyunu xalq tamaşası. Bakı: İşıq, 1984, 275 s.

\section{BIBLIOGRAPHY}

2. Hacıbəyli Ü. Seçilmiș əsərləri. 2 cilddə, II cild. Bakı: Şərq-Qərb, 2005, 455 s.

3. Həsənov K. Qədim Azərbaycan xalq rəqsləri. Bakı : işıq, 1983, 60 s.

4. Hüseynzadə R. Qədim və erkən orta əsrlərdə Azərbaycanda tərbiyə, təhsil və pedaqoji fikir. Bakı : Nurlan, 2007,336 s.

5. Kərimov R. Naxçıvan musiqi mədəniyyəti tarixindən: vokal ifaçılıq sənəti. Bakı : Azərnəşr, 2006, $96 \mathrm{s.}$

6. Qəhrəmanov Ә. İfaçiliq sənəti: təkamül yolları. Axtarışlar. AMEA NB İncəsənət, Dil və Әdəbiyyat İnstitutu. Naxçıvan, 2017, № 2 .

7. Qasımov Oli Səbri. Ömürdən yarpaq düşür. Bakı: Gənclik, 1983, 168 s.

8. Məmmədov V. Musiqi, söz, ifaçı. Bakı : İşıq, 1981, 143 s.

9. Naxçıvan Muxtar Respublikasının sosial-iqtisadi və mədəni inkişafının müasir probelmləri. Bakı : Diplomat nəşr, $1998,135 \mathrm{~s}$.

10. Şifahi ənənəli Azərbaycan musiqisi. Bak 1: Qrifnəşr, 2016, $170 \mathrm{s.}$

\section{REFERENCES}

1. El-oba oyunu xalq tamaşası. [El-oba game folk performance ] Baku: İshıq, 1984, 275 p.[in Azerbaijani]

2. Hacıbəyli Ü. Seçilmiş əsərləri. 2 cilddə, II cild. [Selected works. In 2 volumes, II volume ] Baku: East-West, 2005, 455 p. [in Azerbaijani]

3. Həsənov K. Qədim Azərbaycan xalq rəqsləri.[Ancient Azerbaijani folk dances] Baku: Ishıq, 1983, 60 p.[in Azerbaijani]

4. Hüseynzadə R. Qədim və erkən orta əsrlərdə Azərbaycanda tərbiyə, təhsil və pedaqoji fikir. [Upbringing, education and pedagogical thought in Azerbaijan in ancient and early medieval times] Baku: Nurlan, 2007, 336 p.[in Azerbaijani]

5. Kərimov R. Naxçıvan musiqi mədəniyyəti tarixindən: vokal ifaçılıq sənəti.[ From the history of Nakhchivan music culture: the art of vocal performance] Baku: Azerneshr, 2006, 96 p.[in Azerbaijani]

6. Qəhrəmanov Ә. İfaçiliq sənəti: təkamül yolları.[ Performing arts: ways of evolution] Researchs. NASA NB Institute of Art, Language and Literature. Nakhchivan, 2017, №-2 [in Azerbaijani]

7. Qasımov Oli Səbri. Ömürdən yarpaq düşür.[ A leaf falls from life] Baku: Ganclik, 1983, 168 p.[in Azerbaijani]

8. Məmmədov V. Musiqi, söz, ifaçı.[ Music, words, performer] Baku: İshıq, 1981, 143 p. [in Azerbaijani]

9. Naxçıvan Muxtar Respublikasının sosial-iqtisadi və mədəni inkişafının müasir probelmləri. [Modern problems of socio-economic and cultural development of the Nakhchivan Autonomous Republic] Baku: Diplomat press, 1998,135 p. [in Azerbaijani]

10. Şifahi ənənəli Azərbaycan musiqisi. [Oral traditional Azerbaijani music] Baku: Qrifpress, 2016, 170 p. [in Azerbaijani] 